\title{
4. The public servant as analyst, adviser, and advocate
}

\author{
David Bromell
}

Much of the work of public officials - elected or appointed - involves choices amongst values; indeed, it is this characteristic of their role in a liberal democracy that often makes their decisions contestable, debateable and requiring public justification. Therefore, nothing is more dangerous to the well-being of the body politic than a public official who is technically competent or strategically astute but ethically illiterate or unfit. (Preston 1994, p. 1).

\section{Introduction}

Public servants involved in policy making fulfil at least three distinct functions within Westminster-style parliamentary democracies: those of analyst, adviser, and advocate (cf. Gallagher 1981, pp. 72-3). These functions are not necessarily distinguished by role or position and correspond to the interplay between information, interests, and ideology in public policy making (Weiss 1983).

This paper explores tensions within and between analysis, advice giving, and advocacy, and proposes that the three functions be distinguished without separation or division. Maintaining appropriate distinctions is, in fact, encouraged in law and by convention, ethical codes of practice, and statements of public sector values. It requires above all, however, the intentional cultivation of what Kenneth Winston $(2002,2009)$ has termed 'moral competence in public life' and its institutionalisation through public sector management and leadership.

\section{The analyst}

As analyst, the public servant collects and analyses data and other information and provides this to ministers, parliament, and the public. Examples include preparing departmental annual reports for the portfolio minister to table in the House of Representatives, assisting Vote ministers with Estimates debates, 
providing information to and appearing as witnesses or advisers before select committees, assisting with responses to parliamentary questions and ministerial correspondence, providing briefings to ministers and their staff, and responding to requests made under the Official Information Act 1982. In this role, the public servant is expected to be technically competent and politically neutral.

Policy analysis also commonly requires public servants to articulate two or more options, using an appropriate 'evidence base' and analytical framework or frameworks, in order to enable the government to determine its preferred means to achieve its agreed ends. Those ends are defined by the manifesto commitments and electoral mandate of the party that leads the government, by coalition and confidence-and-supply agreements with minor parties, and by direction provided from time to time by ministers and cabinet. In this sense, the public servant is an implementer and 'rational functionary' (Parsons 1995, p. 7), who 'faithfully serves the government of the day' by aligning public administration with government priorities.

A positivist account of policy analysis, and of the role of social science in public policy, requires the separation of facts and values, means and ends. Callahan and Jennings (1983, p. xvii; cf. Moroney 1981, p. 81) describe this 1960s-1970s approach, whereby policy analysis was taken to be primarily an administrative, technical activity concerned with the efficient fitting of means to given ends:

Having been assigned a particular goal by the policymaker (who, in turn, was acting on authority delegated by democratically elected representatives), the social scientist was to analyze particular policy options which, on the basis of empirically confirmed generalizations about human behaviour, could be evaluated in terms of their potential consequences, the relationship between costs and benefits, and their likely effectiveness.

State Services Commission guidance reflects this sort of approach (SSC 2007b, p. 13):

The work we do must not be influenced by personal beliefs or commitments. These personal interests can be wide-ranging, including party political, religious, philosophical, and vocational, and can be shaped by all sorts of experiences and upbringing. What we do in our organisation must reflect State Services standards of integrity and conduct and not be undermined by any personal conviction or particular ethical viewpoint we may embrace.

The Frankfurt School, however, and Habermas in particular, has challenged scientistic conceptions of objectivity, which identify objectivity with neutrality and freedom from normative commitments (Nielsen 1983). It is increasingly 
accepted, as Callahan and Jennings (1983, p. xix) argue, that 'even the most quantitative and formalistic policy-analytic techniques contain concealed value choices and inextricable normative implications'.

This requires the public servant as analyst to manage tensions between the objective and the subjective nature of reality (and hence the empirical and the normative) and between short-term alignment to government priorities and longer-term responsibility to the public good. Quite apart from the incomplete and imperfect information we have to work with, no analyst is a purely 'rational functionary'. We all have complex interests, values, beliefs, ideologies, and goals of our own that cannot be entirely separated from 'evidence-based' public policy analysis (Parsons 1995, pp. 7, 87-8; Bardach 2000, p. xiii). These shape our perceptions of reality and influence, in particular, the critical 'problem definition' stage in policy analysis (Parsons 1995, p. 88, emphasis in original):

policy analysts could be said to be in the business of problem-structuring and ordering so as to facilitate problem-solving by decision-makers. Politics arises because we do not share perceptions of what the problems are, or if we do, what follows from the definition in terms of what can be or should be done. A definition of a problem is part of the problem.

Geva-May (1997, p. 4) similarly reflects that:

Casting and recasting the problem is one of the most important functions a policy analyst performs. Problems do not exist as objectively defined entities out there 'waiting to be solved'. Rather, a single set of conditions can yield any number of problems depending, among other things, on the reference frame of interested parties.

Analysts are, thus, not a species of social scientist in the (positivist) sense of 'technicians of the social life' (Nielsen 1983, p. 117); neither can the mere fact of electoral competition alone be expected to carry normative weight, given the imperfection of democratic institutions and processes (McPherson 1983, pp. 69, 75-6). The analysis of data and information is, therefore, somewhat indirect - 'one small piece in a larger mosaic of politics, bargaining, and compromise' (Callahan and Jennings 1983, p. xiii). Nevertheless, there is a continuing expectation that public sector analysis will be evidence-informed, professional, and politically neutral.

A further challenge for the public servant as analyst is to balance short-term priorities against long-haul thinking about hard questions and 'wicked problems' (Rittel and Webber, 1973; Australian Public Service Commission 2007). Public servants are required to be responsive to government priorities and to support their ministers in aligning policies, programmes, and services to those priorities. Ministers naturally tend to be focused on the short term and the three-year 
electoral cycle. The Westminster system of a permanent, professional public service also requires, however, investment in medium- to long-term analysis that may not be immediately important to the current government but may prove critical, nevertheless, to the public sector's ability to respond to future crises and priorities of the next government or the one after that. The system is based on the idea that governments, present and future, will be served well when the public service retains 'expertise, institutional memories and wisdom about good policy which is developed over years' (Scott 2008, p. 12).

The tension between short-term alignment and medium- to long-term policy development is highlighted when ministers themselves demand, on the one hand, alignment to current priorities, 'exploitation' rather than 'exploration' modes of research and evaluation (Lindquist 2009, p. 15) that enable rapid evidence assessment (Rapid Evidence Assessment Toolkit n. d.) and 'real-time learning' and, on the other hand, innovative and forward-thinking 'transformative' approaches to emerging challenges and 'wicked problems' (Baehler and Bryson 2009, pp. 15, 17).

\section{The adviser}

As adviser, the public servant is responsible for 'speaking truth to power' (Wildavsky 1987), providing advice to the government of the day that is 'free and frank' (SSC 2007a, 2007b, p. 14). In the Westminster system of government, this advice is to be professional, politically neutral, and of such integrity as to maintain the confidence of present and future ministers, parliament, and the public (SSC 2007b, pp. 13, 14, 16, 2008c, p. 4).

At the same time, public servants are required to 'faithfully serve the government of the day' by implementing its policy decisions, once made, without criticism or re-litigation (SSC 2008c, pp. 5-6). In doing so, public servants are further expected to uphold duties to the public to protect the interests of society generally through the manner in which policies are implemented and programmes and services delivered (Woodward 1994, p. 228).

This raises the question of what 'success' looks like in the policy advice role (Radin 2000, p. 28; cf. Bardach 2000, pp. 23-4). Is the adviser successful when the agreed policy 'outputs' have been delivered within the agreed timeframes? When decision makers have been convinced to adopt the adviser's recommendations? When decision makers are helped to understand the complexities and dimensions of a policy choice (which may result in a different policy being adopted)? When a policy adopted by decision makers has broad public support? When, with or without public support, a policy is endorsed by key stakeholders or academic experts? When the policy is consistent with 
the nature, aims, and purposes of public services and the values inherent in these? When policy once implemented can be demonstrated to have improved outcomes for citizens? The answer, of course, is some combination of all of the above.

This in turn implies that the public servant as adviser juggles conflicting demands from multiple clients. As Martin (1994, p. 106) explains:

Currently the accepted expression in New Zealand of the duty of a public servant (within the law) is that 'the minister is my client'. This immediately throws into relief the claims of competing duties: to the government-as-a-whole? to the public? to the chief executive (who is the employer)? to values such as justice, democracy, efficiency or rationality?

Advice, moreover, has become highly contestable, with a growing demand from ministers for advice sourced from beyond the public service and an increasing number of 'political' (or 'ministerial') advisers being employed to support their ministers in advancing the government's political and policy agenda (Eichbaum and Shaw 2005, 2007, 2010; cf. SSC 2008c, pp. 7-8). Political advisers can play a useful role within New Zealand's mixed-member proportional electoral system, assisting with negotiations around the formation of a government, managing relationships between the government and its coalition and parliamentary support parties, and assisting ministers to prepare political (as distinct from factual) responses to parliamentary questions and ministerial correspondence. There are risks, however, that political advisers may filter and contaminate the free flow of information and communication between ministers and departmental officials, dilute the robustness of officials' advice, and provide ill-informed and uncritical second-opinion advice on policy proposals (Pollitt 2003, p. 87). Consequently, the employment of 'political advisers' in New Zealand, Australia, and the United Kingdom has not occurred without criticism (Uhr 2005, p. 25; Hood and Lodge 2006, p. 159; Lodge 2009, p. 53; Scott 2008, p. 5).

The challenge for the public servant as adviser is to balance rigour and relevance in the real-world hurly-burly of politics. As Gregory $(2005$, p. 26) puts it:

Analysis can be rigorous (but of course it sometimes/often is not) but it may also be rigorously irrelevant (to actual policy-making) if it does not speak constructively to the agendas that are driving decision makers.

Neutrality is, in this sense, a naïve and even dangerous aspiration. Gregory (2005, p. 27) cites Brian Chapman (1959, p. 275): 
Neutrality in public office tends in the end to moral corruption. If all governments are to be served with equal impartiality and loyalty there are no grounds at all for criticizing the German official who served Hitler to the best of his ability.

Consequently, Gregory (2005 p. 27) argues that:

Government officials as individuals must retain, even nurture, a capacity for personal reflective judgement, even as they work in contexts and roles which by their nature insidiously limit that capacity.

Government officials ought, moreover, act to preserve and protect the integrity of the process and the broader democratic values they serve as public servants. McPherson (1983, p. 76) sums up the issue like this:

We can catch some of the complexities here by saying that the adviser really has a three-sided obligation: (1) to serve his or her superiors honestly, (2) to promote better policies, and (3) to respect and improve the democratic process by which decisions are made.

\section{The advocate}

Public servants are to be 'imbued with the spirit of service to the community' (State Sector Act 1988, para (a) of the Long Title). A frequently voiced motivation, in fact, is the desire 'to make a difference', according to personal and (actual or assumed) collective understandings of such desired outcomes as 'social justice', 'the public interest', or 'the common good'.

Given the convention of offering 'free and frank' advice, can and should advice giving by permanent public servants extend to ends as well as means? Can public servants legitimately advocate for particular social and economic outcomes within the performance of their public duties? And how are public servants to balance their desire (and obligation) 'to do the best for New Zealand' with narrower policy agendas and demand for short-term fixes within typical government policy processes (Baehler and Bryson 2009, p. 17)?

Policy making involves, indeed requires, political argument. As Wildavsky (1987, p. 13) puts it, 'Analysis, which is in part rhetoric, should be persuasive'. If carried beyond the modelling and alternative design stages of the policydevelopment process, the analyst's search for rationality and neutrality can be nothing more than an ill-conceived attempt to side-step the demands of democratic contestation (Radin 2000, pp. 92, 104). To be effective, advisers must 
have regard for the authorising environment and the ideological and political preferences and perspectives of decision makers (Scott 2008, p. 2), and it is naïve to pretend otherwise. Geva-May (1997, p. 145) explains:

Neutrality serves policy analysis well during evaluation conduct - at the modelling and alternative design stages - but it becomes impedimentary once findings and recommendations are presented, discussed and acted on by organizational actors. Then it becomes subjected to the power and politics of major organizational players. Lacking advocacy and organizational basis, proposals have little capacity of survival.

Moving into an advocacy role as a public servant, however, is a risky business. In an increasingly pluralistic society, whose 'common good' is the public servant advocating for? Whose interests, values, ideology, and vision of what is 'best for New Zealand' are to be voiced? And how are unelected officials accountable to the public for the advocacy they engage in?

Hawke (1993, p. 37) urges policy advisers to focus on the issue, not a routine application of individual beliefs, because, 'Working together may be damaged by officials following their own agendas rather than showing commitment to the policy process. Officials have varying beliefs and values, personality differences and distinctive professional backgrounds'. State Services Commission guidance further reminds us that (SSC 2008b, p. 3):

A partisan statement made or position adopted by a State servant may not be forgotten easily and it could colour the way that Ministers (or future Ministers) relate to that State servant or to the agency employing that person. The consequences could be to reduce the credibility of the State servant and the agency (and the State Services generally).

What, then, are the options? Radin (2000, p. 101) identifies three.

- Move away from high-profile roles and assignments to less visible activity, and accept that one's impact will be only at the margin of decisions (the details of policy design and implementation) rather than the contours of the policy itself.

- Exit the public sector and become identified with particular political or value commitments; that is, move into an explicit advocacy posture.

- Attach oneself directly to political actors (for example, as a 'political adviser') or stand for elected office and move into a decision-making role.

There is, of course, a fourth option (most commonly pursued by public servants): live with and manage role proliferation and confusion (Baehler and Bryson 2000, p. 17) 
by exercising judgement on a case-by-case basis and seeking advice as required from one's manager, chief executive, or the State Services Commission (SSC 2008a, pp. 3, 8).

\section{A Chalcedonian challenge}

The fifth-century Christian churches were divided over whether, how, and to what extent the second person of the Trinity could be both fully human and fully divine. As in all disputes over big ideas, the arguments were as much political as doctrinal. In 451, the emperor Marcian issued a decree, on behalf also of the Western Emperor Valentinian III, calling an ecumenical council to address this and other issues.

The council met in October 451 in Chalcedon, a city in Bithynia in Asia Minor (now part of the greater city of Istanbul, on the Asian side of the Bosphorus). In the fifth session, held on 22 October, the bishops published the Chalcedonian Definition of the Faith, which asserts that 'the one and the same Christ, Lord, and only-begotten Son, is to be acknowledged in two natures without confusion, change, division, or separation (in duabus naturis inconfuse, immutabiliter, indivise, inseparabiliter)'.

Notwithstanding the resulting major schism between Eastern Orthodox and Western churches, I propose that public service functions of analysis, advice giving, and advocacy be similarly distinguished without separation or division. This is because the three functions correspond to an inescapable interplay between information, interests, and ideology (or fact, value, and theory) in public policy making (Weiss 1983; Gregory 2005; Rein 1983, p. 83).

The challenge for the public servant is to live creatively with the tensions within and between the three functions of analysis, advice giving, and advocacy, maintaining appropriate distinctions and exercising sound judgement - and to do so within inevitably imperfect democratic institutions and processes. Public sector policy making occurs within a real-world context of conflict over facts and values, information and power, means and ends, and where multiple, complex, and complicated 'public service bargains' (Hood and Lodge 2006) are operative.

What then, are the principles, values, and institutional arrangements that might guide and support public servants to make and maintain appropriate distinctions between analysis, advice giving, and advocacy, without separating or dividing them? 


\section{Public sector ethics}

Public sector ethics are promoted, explicitly or implicitly, by:

- legislation and convention

- codes of conduct

- statements of public sector and organisational values.

\section{Legislation and convention}

The roles and requirements of the New Zealand public service are legislated in the State Sector Act 1988, Public Finance Act 1989, and Official Information Act 1982, as well as in statutes that govern particular agencies and their functions (for example, the Education Act 1989 and Children's Commissioner Act 2003). Legislation and convention support four broad propositions, as identified by the Right Honourable Sir Kenneth Keith in his introduction to the Cabinet Manual (Keith 1990, p. 4). Members of the public service are:

- to act in accordance with the law

- to be imbued with the spirit of service to the community

- (as appropriate) to give free and frank advice to ministers and others in authority and, when decisions have been taken, to give effect to those decisions in accordance with their responsibility to the ministers or others

- when legislation so provides, to act independently in accordance with the terms of that legislation.

Sir Kenneth adds (p. 5), 'Public servants meet those obligations in accordance with important principles such as neutrality and independence, and as members of a career service'. In other words, public service occurs within a democratic compact whereby society delegates coercive powers to the state but does so on the understanding that public powers are to be exercised for the public good, in accordance with the law, and with forbearance, good reason, and transparency.

\section{Codes of ethics and conduct}

In a pluralist society, individually generated moral beliefs, values, or principles are unlikely to constitute a coherent and consistent body of ethical guidance for public service. While public servants certainly have private lives, the ethics we are concerned with here relate primarily to the performance of public duties (Uhr 2005, p. 10). What is required is a set of norms that is socially constructed 
in such a way as to align individual behaviour with institutional purposes (Hardin 2006). These sets of norms are commonly articulated in the form of codes of ethics or conduct.

In an independent survey of New Zealand state services integrity and conduct (Ethics Resource Center 2007), 75 per cent of those who had observed misconduct believed it breached the organisation's standards of integrity and conduct, rather than the law or both combined. State servants commonly recognise, therefore, a distinction between what is legal and what is ethical.

In New Zealand, the first written public service code of conduct was issued by the State Services Commission in 1989 (Hicks 2007, p. 12). This was followed by a comprehensive guidance series (SSC 1995) on public sector ethics and standards. In 2001, a revised state services code of conduct was issued (SSC 2001), and accompanying guidance material later developed (SSC 2007a, 2007b).

In addition, many public sector agencies have their own codes of conduct. The Ministry of Social Development's code applies to all employees, contractors, and consultants who are working for the ministry on a full-time, part-time, temporary, or casual basis (MSD n. d., a). The code is both aspirational, setting out 'principles that guide the way we work', and disciplinary, establishing specific responsibilities and outlining investigation processes and the likely consequence of disciplinary action should the code be breached.

As Rhode (2006, p. 34) notes:

Codes of conduct can clarify rules and expectations, establish consistent standards, and project a responsible public image. If widely accepted and enforced, codified rules can also reinforce ethical commitments, deter ethical misconduct, promote trust, reduce the organization's risks of liability, and prevent free riders (those who benefit from others' adherence to moral norms without observing them personally).

On the other hand, codes tend to restrict only the behaviour of those who are already ethical (Sampford 1994, p. 20). Codes also do not clarify the standards public servants should aspire to, and against which they will, or ought to be, assessed. As Uhr (2005, p. 38) comments:

It is one thing to know that corruption means conduct falling below the standard; it is another to know how far above that standard official conduct should go, or aspire to go, in the direction of, for example, honesty and impartiality.

Moreover, as Uhr (2005 p. 140) adds, 'No code is any better than the competence of those empowered to investigate its breaches'. Rhode (2006, pp. 34-5) 
acknowledges that codes of conduct, in particular, are less effective in promoting ethical behaviour than are 'approaches that stress values by encouraging selfgovernance and commitment to ethical aspirations'.

\section{Statements of organisational values}

As well as codes of conduct, many agencies, including the Ministry of Social Development (MSD n. d., b) have statements that define organisational vision, purpose, and values. In addition, the ministry's leadership team developed a set of operating principles in 2008 that is reproduced on internal stationery and the ministry's intranet:

\section{Ministry of Social Development (MSD) Principles}

MSD PEOPLE:

- put people first

- team up to make a bigger difference

- act with courage and respect

- empower others to act

- create new solutions

- are 'can do', and deliver

- honour achievement.

Above all, we do the right thing for New Zealanders.

The OECD (2000, p. 2) advises that, 'Identifying core values is the first step to creating a common understanding within society of the expected behaviour of public office holders'. The eight most frequently stated core public service values in OECD countries in rank order are impartiality, legality, integrity, transparency, efficiency, equality, responsibility, and justice. A survey of public organisations in Canada (Kernaghan 1995) identified 19 core values in the following rank order: integrity and ethics, accountability and responsibility, respect, service, fairness and equity, innovation, teamwork, excellence, honesty, commitment and dedication, quality, openness, communications, recognition, responsiveness, trust, effectiveness, professionalism, and leadership.

As can be seen from these lists, values statements commonly contain a broad mix of goal values (where we want to go) and conduct values (how we will get there) (Starling 2008, p. 183). Pollitt (2003, p. 135) has further classified these as: 
- democratic values (serving the common good rather than sectional interests, promoting public accountability, supporting elected representatives, always observing the law)

- professional values (promotion by merit, continuous improvement, impartiality, effectiveness, creativity, loyalty to professional colleagues, putting the client's interests first)

- general ethical values (integrity, honesty, equity, probity)

- people values (reasonableness, civility, respect for difference, kindness).

Statements of organisational values need to reflect and be integrated with the purpose of the agency, so that policy, programme, and process are coherent (Gawthrop 1984, p. 120; Rein 1983, pp. 86-7). Ideally, as Sampford (1994, p. 19) argues, they are created and reviewed regularly with and by the staff who are to work in accordance with them:

If you want people to behave ethically and internalise the relevant values, you have to get the staff who will live by them to take an active part in their creation. Do not just give them the rules but ask them to look at the ways in which their practice is ethically vulnerable, to discuss such vulnerabilities and to reflect on the kinds of rules they should adopt for themselves.

Values statements are empty rhetoric unless they are embodied in and expressive of institutional design, work processes, recruitment, and performance management and are consistently modelled by chief executives and their senior staff.

\section{Moral competence in public life}

Distinguishing public service functions of analysis, advice giving, and advocacy without separating or dividing these functions is encouraged and supported by legislation and constitutional convention, codes of conduct, and the promotion of public sector and organisational values. In my experience as a public servant, however, even in combination these are necessary but not sufficient. They are more effective at drawing the line at unethical behaviour than at enabling staff consistently to exercise sound judgement in the normal course of their duties, let alone when we are put on the spot and must decide quickly how to respond or act. This is particularly the case because the hard choices in public policy making are 'not just between right and wrong, or good or bad, or just and unjust, but between right and most right, or ethical and most ethical' (Hicks 2007, p. 11). 
'Walking the line' requires what Winston (2002, 2009) has termed 'moral competence in public life'. The generic attributes that Winston (2009, p. 1) regards as constituent components of moral competence are 'not character traits or personal virtues in the ordinary sense, but qualities of those acting in their official capacities'. In other words, public servants, like all citizens, cannot escape exercising 'personal reflective judgment' (Gregory 2005, p. 27), but the judgement required in the exercise of public service is about what the purpose and principles of the political order require in a particular case, rather than what the public servant might personally like or approve (McPherson 1983, pp. 77-8).Winston $(2002,2008,2009)$ defines six components of moral competency.

1. Civility - the duty to act only on the basis of principles that citizens could reasonably accept (cf. Rawls 1999).

2. Fidelity to the public good - and the dual responsibility this implies to the 'appointing officer' and to broader considerations of the public good (that is, able to reconcile partial and general perspectives).

3. Respect for citizens as responsible agents - balancing concern for citizens' well-being with respect for citizens' individual and collective abilities to set goals, develop commitments, pursue values, and succeed in realising them.

4. Proficiency in democratic architecture - skilled in exercising deliberative judgement about the interplay between ends and means and in facilitating citizen participation in decision making.

5. Prudence - the practical wisdom to make sound moral judgements in concrete situations, including tolerance of moral ambiguity and the ability to learn from recurrent perplexities and tensions.

6. Double reflection - the ability to discern what a course of action might mean to another person when at variance with one's own understanding, and to contemplate with equanimity the contestability of one's own worldview.

To simplify matters, I propose that components 1 and 6 be merged, as also components 3 and 4 . Thus, the moral competencies required for public service are fourfold: civility, fidelity to the public good, respect for citizens as responsible agents, and prudence.

\section{Civility}

Civility is the capacity to engage in reasoned, reflective judgement that makes itself accountable to a diverse public. That is, it requires the recognition of diversity and some level of commitment to a politics of difference and to democratic inclusion (Bromell 2008, 2009a, 2009b). It follows Dewey $(1927,1939)$ 
in understanding democratic decision making as a mode of communication and experimentation in which ideas are exchanged in a public manner and problems solved through experimentation, testing, and learning. It does not aspire to 'pure' rationality, but rather 'communicative rationality' (Habermas 1984), whereby people who live together in difference (and the conflicts this creates) engage in inter-subjective communication about facts, values, and preferences in order to arrive at a workable and more or less common understanding within a given social context at a particular point in time. This may require different modes of reasoning and argument, facility in dealing with incomplete and 'pluralist' rather than 'monist' information (Sen 1985), and different modes of communication; so while it will not be uniform, it is nevertheless internally consistent, transparent, and subject to contestation as public deliberation.

What must not be lost in the 'policy circus' (deLeon 1994, p. 202) with its less than rational stunts and tricks is precisely the imperative of publicity, or the liberal restraint principle. As Baehler (2005, p. 6) expresses this:

Citizens (including officials) who propose policies that involve coercion of their fellow citizens ought to restrain from using non-public reasons to support those proposals, out of respect for each other and the democratic system. Public reasons are understood as the kinds of reasons that other reasonable people might accept as reasonable without necessarily having to agree with them.

Baehler (2005, p. 7) goes on to propose the following features of a public argument model for public policy, which usefully summarise some practical implications of civility.

- Establish clear principles and rules of thumb to distinguish public and nonpublic policy rationales.

- Scan the ideological and evidence terrain and build multi-dimensional cognitive maps of a policy field, including both descriptive data and competing policy approaches in ideological space.

- Develop better methods to build and test public arguments.

- Use evidence as one ingredient (linked with logic, linked with an appeal to people's values) to build and support the argument framework.

- Engage ministers in the shared goal of building public good arguments.

\section{Fidelity to the public good}

Fidelity to the public good requires skill and responsibility in dealing with vast complexity and dynamic change along the horizontal continuum of time, as 
distinct from being merely responsive to the demands of the present moment and to vertical accountabilities. Public sector organisations ought not to be merely reactive and incremental. Fidelity to the public good requires rather 'a sense of purpose that transcends the present and serves as a sense of direction in shaping public policies to improve the long-term well-being of society' (Gawthrop 1984, pp. 120-1). Fidelity to the public good requires a sense of purpose, a sense of consequence, a sense of history. It requires responsibility as well as responsiveness.

Fidelity to the public good means public servants go about their work in such a way as to maintain the confidence of future as well as present ministers, parliament, and the public. It means 'faithfully serving the government of the day' without being captured by it or losing longer-term perspectives inherent in being public (as distinct from government) servants. It means engaging in the sorts of research and evaluation that enable an estimation of trends in citizens' well-being over time. It requires attention to issues of intergenerational equity and to a horizontal sense of purposefulness over medium- to long-term timeframes that is convergent and consensus building. It requires building and maintaining a professional public service.

\section{Respect for citizens as responsible agents}

Respect for citizens as responsible agents is a necessary moral competence, if as a society we want to do better than implement paternalistic (or 'nanny state') welfarism through a cadre of technocratic bureaucrats and 'we know best' political masters and mistresses.

As Amartya Sen (1985, 1999; cf. 2009, ch. 13) has argued, both the 'well-being aspect' and the 'agency aspect' of persons are relevant to the assessment of states of affairs and actions. He distinguishes (1985, pp. 203-4) agency freedom as 'open conditionality':

Whereas well-being freedom is freedom to achieve something in particular, viz., well-being, the idea of agency freedom is more general, since it is not tied to any one type of aim. Agency freedom is freedom to achieve whatever the person, as a responsible agent, decides he or she should achieve.

This open conditionality does not imply that a person's view of their own freedom is beyond challenge or constraint. Aims, objectives, and consequences for the public good all need to be assessed, and agency freedom exercised as responsible freedom. 'But', Sen (1985, p. 204) adds, 'despite this need for 
discipline, the use of one's agency is, in an important sense, a matter for oneself to judge'; that is, the substantive freedoms (the capabilities) to choose a life one has reason to value (Sen 1999, p. 74).

Respect for citizens as responsible agents requires skill in situating public policy between power and rationality (Arts and Van Tatenhove 2004), in managing increasing demands for subsidiarity, 'multi-actor' or 'network' governance, and citizen 'co-production' (Alford 2009a, 2009b), and in otherwise facilitating citizen participation in self-government. Wildavsky (1987, p. 255) argues that, 'Whatever else policy analysts may be ... they should be advocates of citizen participation. ... Designing policies that facilitate intelligent and effective participation is an essential task of policy analysis'.

\section{Prudence}

Prudence is the exercise of practical and not only technical reason to make moral judgements in concrete situations (that is, within the limits and opportunities of specific social and historical contexts) that can be challenged and defended through an exchange of public reasons.

Technical reason is the rational selection (using techniques such as cost-benefit analysis) of instrumental means to achieve given ends. Practical reason concerns the acceptance or rejection of norms, especially norms for action, the claims to validity of which can be supported or opposed with public reasons (Habermas 1974, p. 3).

Robert Bellah (1983, p. 55) argues that practical social science should take priority over technocratic social science and that the purpose of prudential practice is not to produce or control anything but to discover through mutual discussion and reflection between free citizens the most appropriate ways, under present conditions, of living the ethically good life'. Accordingly, its vocabulary is the common moral vocabulary of a free society, with justice, equality, and freedom among its basic terms (p. 62).

Practical social science can only ever hope to achieve 'disciplined knowing', not the degree of certainty that might be expected in the physical sciences. Prudence is required precisely because scientific demonstration is not possible (Bellah 1983, p. 64). Public policy making is, for this reason, more art and craft than science, 'a projection of frames of reference on reality, around which action is taken' (Geva-May 1997, p. xxii). It focuses, as per Socrates, on 'What ought one to do?' rather than on 'What is right, what is wrong?' or 'What is good, what is evil?' (Longstaff 1994, p. 142). It draws on cumulative experience to make strategic, contingent judgements in the full awareness of moral ambiguity, the fallibility of human planning, and the inevitability of unintended consequences (Winston 2009, p. 5; cf. Uhr 2005, ch. 3). 
Prudence, however, does not replace the need for technical reason. We might rather follow Dewey in seeing the practical and the technical as two indispensable aspects or dimensions of policy making, rather than as two distinct and selfcontained kinds of enterprise (McPherson 1983, p. 71). Policy making may be more art and craft than science (Wildavsky 1987, ch. 16), but the sound application of technical reason can help prevent the craft from being exercised in ways that are merely 'crafty'.

\section{Moral leadership}

How, then, might the cultivation of moral competence in public life be encouraged and supported, and institutionalised through public management and leadership?

In a career public service where everyone starts as a cadet and has opportunity for eventual promotion to leadership roles only by working their way up through the ranks, sound judgement can be cultivated through the accumulation of experience and relationships forged with one's seniors and peers, who have likewise had long-term exposure to the purpose, values, and principles that govern the agency and wider public service. Promotion and reward are tied, moreover, to behaviours aligned with the agency's ethos (cf. Hood and Lodge 2006, pp. 168-9).

In New Zealand, this model now applies only in the defence force and police. It has previously applied in the Ministry of Foreign Affairs and Trade, which has offered a 'lifetime career path', but even senior positions in the ministry are now being opened up to people with wider public or private sector experience. I myself came into the public service mid-career.

If we assume that, for various reasons, the days of a lifetime career public service are numbered, then the cultivation of moral competence in public life depends on staff recruitment, training, and development, and, above all, on the exercise and modelling of moral leadership by chief executives and their senior staff.

Recruiting and retaining a workforce with diverse professional backgrounds and academic training (arts and humanities as well as 'soft' and 'hard' sciences) is one protection against a 'group think' application of technocratic reason to public policy making. Ethics can also be taught - in the sense that public servants can learn to think more reflectively and systematically about professional practice and to engage with others in critical reflection on 'hard cases' (cf. Dworkin 1977, ch. 4). There certainly ought to be a place in the induction of new employees for an introduction to public sector ethics, the state sector code of conduct, and the agency's own code, purpose, values, and principles. This should be more than 
a cursory formality whereby the employee signs that they have received a copy and read it, but rather the initiation of a continuing process of critical reflection on the ethics of public service and the ethos of the employing agency. In the 2007 survey of New Zealand state services integrity and conduct, although 55 per cent of state servants believed their organisations provide training on standards of integrity and conduct, just more than one in five reported that they 'do not know' whether their organisation does (Ethics Resource Center 2007, p. 5). The Ethics Resource Center recommended (2007, p. 9), 'In order to promote a strong ethical culture and foster positive outcomes, establish programmes that are consistent, genuine, and relevant to the needs of State servants'.

As Preston (1994, p. 6) notes, however, 'The teaching of ethics to those determined to be corrupt or unethical is unlikely to make a difference'. Ethics is caught rather than taught, and if we concentrate only on the individual's behaviour, or narrowly focus on 'risk and assurance' in the prevention and detection of unethical behaviour, the impact on public sector ethics will be limited (Rhode 2006, pp. 34-5). What is required is rather the socialisation and institutionalisation of ethics within the structure, relationships, and distribution of power within public sector organisations (Preston 1994, p. 8; Sampford 1994).

I have myself benefited from opportunities to work alongside older and more experienced public policy practitioners. Trusting relationships with senior colleagues have provided me with 'sounding boards' and 'safe space' for critical reflection on 'doing the right thing' as a public servant. This implies deliberate attention to organising workplace teams in ways that maximise formal and informal contact and mentoring between 'wise hands' and less-experienced staff, and not so overloading principal analysts and advisers with project work that they are unable to contribute as mentors and coaches to more junior staff in any significant way or to provide robust second-opinion advice.

Ultimately, however, what makes or breaks public sector ethics is the tone created by chief executives and their senior staff. And what most counts is not what we say and do on the good days but how we conduct ourselves when confronted with ambiguity in the performance of our public duties 'the disquieting internal tension that comes from competing duties, colliding considerations, and dissonant emotions' (Rhode 2006, p. 85). Rhode further reminds us that, 'No corporate mission statement or ceremonial platitudes can counter the impact of seeing leaders withhold crucial information, play favorites with promotion, stifle dissent, implement corrosive reward structures, or pursue their own self-interest at the organization's expense' (p. 39). She particularly urges senior managers to solicit diverse perspectives and dissenting views, on the grounds that a defining feature of moral leadership is a willingness to ask and to hear uncomfortable questions (p. 40). 
Moral leadership demands going beyond responsiveness to responsibility; beyond doing no wrong, to doing the right thing (Hanson 2006, pp. 291-2; cf. Uhr 2005, ch. 8). And whether or not chief executives do in fact provide moral leadership will depend, in large part, on the incentives and accountabilities that apply to them and the transparency of those incentives and accountabilities.

\section{Conclusion}

This chapter has analysed tensions within and between public policy functions of analysis, advice giving, and advocacy. It has proposed that, because of the inescapable interplay between information, interests, and ideology in public policy making, the three functions need to be distinguished, without separation or division.

While maintaining appropriate distinctions can be encouraged in law and by convention, ethical codes of practice, and statements of public sector and organisational values, ethical policy making requires above all the intentional cultivation of 'moral competence in public life'. Four key competencies are civility, fidelity to the public good, respect for citizens as responsible agents, and prudence. The long-term integrity of a professional public service depends on the socialisation and institutionalisation of these competencies through public sector management and leadership that is moral and not narrowly or merely 'ethical'.

\section{References}

Alford, J. 2009a. Engaging Public Sector Clients: From service delivery to co-production. Basingstoke, Hampshire: Palgrave Macmillan.

Alford, J. 2009b. Public Value from Co-production by Clients. Working paper. Australia and New Zealand School of Government. http://ips.ac.nz/events/ downloads/2009/Building\%20the \%20Public\%20-\%20Spring \%20Series (accessed May 2010). (Forthcoming in J. Benington and M. Moore (eds). In Search of Public Value. London: Palgrave Macmillan.)

Arts, B., and J. Van Tatenhove. 2004. 'Policy and power: A conceptual framework between the 'old' and 'new' policy idioms.' Policy Sciences 37: 339-56.

Australian Public Service Commission. 2007. Tackling Wicked Problems: A public policy perspective. Barton, ACT: Commonwealth of Australia. www. apsc.gov.au/publications07/wickedproblems.htm (accessed May 2010). 
Public Policy: Why ethics matters

Baehler, K. 2005. 'What are the limits to public service advising? The "public argument" test.' Policy Quarterly 1(3): 3-8.

Baehler, K., and J. Bryson. 2009. 'Behind the Beehive buzz: Sources of occupational stress for New Zealand policy officials.' Kōtuitui: Journal of Social Sciences Online 4: 5-23. www.royalsociety.org.nz/site/publish/journals/kotuitui/ default.aspx (accessed May 2010).

Bardach, E. 2000. A Practical Guide for Policy Analysis: The eightfold path to more effective problem solving. New York and London: Chatham House Publishers.

Bellah, R. 1983. 'Social science as practical reason.' In D. Callahan and B. Jennings (eds). Ethics, the Social Sciences, and Policy Analysis. New York and London: Plenum Press, pp. 37-64.

Bromell, D. 2008. Ethnicity, Identity and Public Policy: Critical perspectives on multiculturalism. Wellington: Institute of Policy Studies, Victoria University of Wellington.

Bromell, D. 2009a. 'Diversity and democracy.' Policy Quarterly 5(4): 29-35.

Bromell, D. 2009b. 'Recognition, redistribution and democratic inclusion.' In R. Openshaw and E. Rata (eds). The Politics of Conformity in New Zealand. North Shore City: Pearson, pp. 231-55.

Callahan, D., and B. Jennings (eds). 1983. Ethics, the Social Sciences, and Policy Analysis. New York and London: Plenum Press.

Chapman, B. 1959. The Profession of Government. London: George Allen \& Unwin.

deLeon, P. 1994. 'Democracy and the policy sciences: Aspirations and operations.' Policy Studies Journal 22(2): 200-12.

Dewey, J. 1927. The Public and its Problems. New York: Holt.

Dewey, J. 1939. Freedom and Culture. New York: Putnam.

Dworkin, R. 1977. Taking Rights Seriously. Cambridge, MA: Harvard University Press.

Eichbaum, C., and R. Shaw. 2005. 'Why we should all be nicer to ministerial advisers.' Policy Quarterly 1(4): 18-25.

Eichbaum, C., and R. Shaw. 2007. 'Minding the minister? Ministerial advisers in New Zealand government.' Kōtuitui: Journal of Social Sciences Online 2: 95-113. www.royalsociety.org.nz/site/publish/journals/kotuitui/default. aspx (accessed May 2010). 
Eichbaum, C., and R. Shaw (eds). 2010. Partisan Appointees and Public Servants: An international analysis of the role of the political advisor. Cheltenham, UK: Edward Elgar Publishing.

Ethics Resource Center. 2007. New Zealand State Services Integrity and Conduct Survey: August 2007. Ethics Resource Centre: Washington, DC. www.ssc. govt.nz/display/document.asp?DocID=6276 (accessed May 2010). Results of a follow-up survey conducted in March 2010 are on the State Services Commission's website (www.ssc.govt.nz/display/home.asp).

Gallagher, J. 1981. 'Models for policy analysis: Child and family policy.' In R. Haskins and J. Gallagher (eds). Models for Analysis of Social Policy: An introduction. Norwood, NJ: Ablex Publishing Corporation, pp. 37-77.

Gawthrop, L. 1984. Public Sector Management, Systems, and Ethics. Bloomington: Indiana University Press.

Geva-May, I. 1997. An Operational Approach to Policy Analysis: The craft Prescriptions for better analysis. Boston: Kluwer Academic Publishers.

Gregory, R. 2005. 'Politics, power and public policy-making: A response to Karen Baehler.' Policy Quarterly 1(4): 26-32.

Habermas, J. 1974. Theory and Practice. London: Heinemann.

Habermas, J. 1984. The Theory of Communicative Action, Vol. 1: Reason and the rationalization of society. London: Heinemann Education.

Hanson, K. 2006. 'Perspectives on global moral leadership.' In D. Rhode (ed.). Moral Leadership: The theory and practice of power, judgment, and policy. Hoboken: Jossey-Bass, pp. 291-300.

Hardin, R. 2006. 'Morals for public officials.' In D. Rhode (ed.). Moral Leadership: The theory and practice of power, judgment, and policy. Hoboken: Jossey-Bass, pp. 111-25.

Hawke, G. 1993. Improving Policy Advice. Wellington: Institute of Policy Studies, School of Government, Victoria University of Wellington.

Hicks, C. 2007. 'A case for public sector ethics.' Policy Quarterly 3(3): 11-15.

Hood, C., and M. Lodge. 2006. The Politics of Public Service Bargains: Reward, competency, loyalty - and blame. Oxford and New York: Oxford University Press. 
Public Policy: Why ethics matters

Keith, K. 1990. 'On the constitution of New Zealand: An introduction to the foundations of the current form of government.' Cabinet Manual 2008. Wellington: Cabinet Office, pp. 1-6. www.cabinetmanual.cabinetoffice.govt. nz/introduction (updated 2008; accessed May 2010).

Kernaghan, K. 1995. 'The emerging public service culture: Values, ethics, and reforms.' Canadian Public Administration 37(4): 614-30.

Lindquist, E. 2009. There's More to Policy than Alignment. CPRN Research Report, Canadian Policy Research Networks. www.cprn.org/doc. $\mathrm{cfm} ? \mathrm{doc}=2040 \& \mathrm{l}=\mathrm{en}($ accessed May 2010).

Lodge. M. 2009. 'Strained or broken? The future(s) of the public service bargain.' Policy Quarterly 5(1): 53-7.

Longstaff, S. 1994. 'What is ethics education and training?' In N. Preston (ed.). Ethics for the Public Sector: Education and training. Leichhardt, NSW: Federation Press, pp. 138-60.

Martin, J. 1994. 'Ethics in public service: The New Zealand experience.' In N. Preston (ed.). Ethics for the Public Sector: Education and training. Leichhardt, NSW: Federation Press, pp. 91-114.

McPherson, M. 1983. 'Imperfect democracy and the moral responsibilities of policy advisers.' In D. Callahan and B. Jennings (eds). Ethics, the Social Sciences, and Policy Analysis. New York and London: Plenum Press, pp. 6981 .

Moroney, R. 1981. 'Policy analysis within a value theoretical framework.' In R. Haskins and J. Gallagher (eds). Models for Analysis of Social Policy: An introduction. Norwood, NJ: Ablex Publishing Corporation, pp. 78-102.

MSD. n. d., a. Code of Conduct. Wellington: Ministry of Social Development.

MSD. n. d., b. Our Vision, Values and Purpose. Wellington: Ministry of Social Development. www.msd.govt.nz/about-msd-and-our-work/about-msd/ourvision-values-and-purpose.html (accessed May 2010).

Nielson, K. 1983. 'Emancipatory social science and social critique.' In D. Callahan and B. Jennings (eds). Ethics, the Social Sciences, and Policy Analysis. New York and London: Plenum Press, pp. 113-57.

OECD. 2000. Building Public Trust: Ethics measures in OECD countries. PUMA Policy Brief No. 7. Organisation for Economic Co-operation and Development.

Parsons, W. 1995. Public Policy: An introduction to the theory and practice of policy analysis. Aldershot, UK and Brookfield, US: Edward Elgar. 
Pollitt, C. 2003. The Essential Public Manager. Philadelphia, PA: Open University.

Preston, N. (ed.). 1994. Ethics for the Public Sector: Education and training. Leichhardt, NSW: Federation Press.

Radin, B. 2000. Beyond Machiavelli: Policy analysis comes of age. Washington, DC: Georgetown University Press.

Rapid Evidence Assessment Toolkit. n. d. UK Government Social Research Service. www.civilservice.gov.uk/my-civil-service/networks/professional/ gsr/resources/gsr-rapid-evidence-assessment-toolkit.aspx (accessed May 2010).

Rawls, J. 1999. The Law of Peoples; with, The Idea of Public Reasons Revisited. Cambridge, MA: Harvard University Press.

Rein, M. 1983. 'Value critical policy analysis.' In D. Callahan and B. Jennings (eds). Ethics, the Social Sciences, and Policy Analysis. New York and London: Plenum Press, pp. 83-111.

Rhode, D. (ed.). 2006. Moral Leadership: The theory and practice of power, judgment, and policy. Hoboken: Jossey-Bass.

Rittel, H., and M. Webber. 1973. 'Dilemmas in the general theory of planning.' Policy Sciences 4(2): 155-69.

Sampford, C. 1994. 'Institutionalising public sector ethics.' In N. Preston (ed.). Ethics for the Public Sector: Education and training. Leichhardt, NSW: Federation Press, pp. 14-38.

Scott, C. 2008. 'Enhancing quality and capability in the public sector advisory system.' Lecture to the Institute of Policy Studies Futuremaker Series, Victoria University of Wellington, 23 September 2008. http://ips.ac.nz/ events/downloads/2008/ScottFuturemakers\%2023-9-08.pdf\%20 (accessed May 2010).

Sen, A. 1985. 'Well-being, agency and freedom: The Dewey Lectures 1984.' Journal of Philosophy 82(4): 169-221.

Sen, A. 1999. Development as Freedom. New York: Anchor Books.

Sen, A. 2009. The Idea of Justice. Cambridge, MA: Belknap Press.

SSC. 1995. Principles, Conventions and Practice Guidance Series. Wellington: State Services Commission. www.ssc.govt.nz/display/document.asp?docid=5798 (accessed May 2010).

SSC. 2001. New Zealand Public Service Code of Conduct. Reprinted 2005. Wellington: State Services Commission. 
Public Policy: Why ethics matters

SSC. 2007a. Standards of Integrity and Conduct: A code of conduct issued by the State Services Commissioner under the State Sector Act 1988, section 57. Wellington: State Services Commission. www.ssc.govt.nz/display/document. asp? DocID=7063 (accessed May 2010).

SSC. 2007b. Understanding the Code of Conduct: Guidance for state servants. Wellington: State Services Commission.

SSC. 2008a. Political Neutrality Fact Sheet No. 1: What is 'political neutrality' and what does it mean in practice? Wellington: State Services Commission.

SSC. 2008b. Political Neutrality Fact Sheet No. 2: Political views and participation in political activities. Wellington: State Services Commission.

SSC. 2008c. Political Neutrality Fact Sheet No. 3: The relationship between the public service and ministers. Wellington: State Services Commission.

Starling, G. 2008. Managing the Public Sector. 8th edn. Boston, MA: Thomson Higher Education.

Uhr, J. 2005. Terms of Trust: Arguments over ethics in Australian government. Sydney, NSW: University of New South Wales Press.

Weiss, C. 1983. 'Ideology, interests, and information: The basis of policy positions.' In D. Callahan and B. Jennings (eds). Ethics, the Social Sciences, and Policy Analysis. New York and London: Plenum Press, pp. 213-45.

Wildavsky, A. 1987. Speaking Truth to Power: The art and craft of policy analysis. New Brunswick, NJ: Transaction Books.

Winston, K. 2002. Moral Competence in the Practice of Democratic Governance. KSG Faculty Research working paper series RWP02-048. http://web.hks. harvard.edu/publications/working papers/citation.aspx?PubId =1145 (accessed May 2010).

Winston, K. 2008. What Makes Ethics Practical. KSG Faculty Research working paper series RWP08-013. http://web.hks.harvard.edu/publications/ working papers/citation.aspx?PubId=5613 (accessed May 2010).

Winston, K. 2009. Moral Competence in Public Life. Occasional paper 4. Melbourne: Australia and New Zealand School of Government and State Services Authority. www.ssa.vic.gov.au/CA2571410025903D/WebObj/ OccPaper_04_Winston/\$File/OccPaper_04_Winston.pdf (accessed May 2010).

Woodward, A. 1994. 'Making ethics part of real work.' In N. Preston (ed.). Ethics for the Public Sector: Education and training. Leichhardt, NSW: Federation Press, pp. 219-36. 